\title{
Post-infectious Bronchiolitis Obliterans and Subpleural Cysts in a 30-month-old Boy with Down Syndrome
}

\author{
NURDIYANA N , FAIZAH MZ², HASNIAH AL ${ }^{1}$ \\ ${ }^{1}$ Department of Paediatrics, ${ }^{2}$ Department of Radiology, Faculty of Medicine, Universiti \\ Kebangsaan Malaysia Medical Centre, Jalan Yaacob Latif, Bandar Tun Razak, 56000 \\ Cheras, Kuala Lumpur, Malaysia.
}

\begin{abstract}
ABSTRAK
Post-infectious bronchiolitis obliterans adalah penyakit yang jarang berlaku. lanya disebabkan oleh jangkitan saluran respiratori bawahan yang kerap, yang menyebabkan saluran pernafasan menjadi sempit secara kronik. Manakala, subpleural cysts ditemui hanya pada 20-36\% pesakit sindrom Down. Kami melaporkan kes seorang kanak-kanak sindrom Down berumur 30 bulan yang mempunyai penemuan menarik pada radiograf HRCT toraks yang menunjukkan dua ciri iaitu bronchiolitis obliterans dan subpleural cysts. Pesakit yang dilahirkan pramatang ini menghidapi jangkitan paru-paru selepas lahir dan kemudiannya mendapat tiga lagi episod jangkitan paru-paru pada umur 18, 19 dan 26 bulan. Beliau mempunyai gejala batuk yang kronik, pernafasan laju dan berbunyi. Pada pemeriksaan fizikal, terdapat tanda-tanda yang menunjukkan masalah saluran pernafasan tersekat yang kronik. Sampel kahak dari nasofarinks didapati positif virus Influenza B. Setakat pengetahuan kami, ini merupakan laporan pertama tentang kewujudan kedua-dua entiti radiologi tersebut pada seorang kanak-kanak sindrom Down.
\end{abstract}

Kata kunci: bronchiolitis obliterans, sindrom Down, subpleural cysts

\section{ABSTRACT}

Post-infectious bronchiolitis obliterans is a rare disease that may occur following a microbiological insult towards the lower respiratory tract causing a severe form of chronic obstructive airway disease. Subpleural lung cyst may occur in 20-36\% of Down syndrome. We report a case of a 30-month-old Down syndrome child who had interesting radiological concurrent findings of bronchiolitis obliterans

Address for correspondence and reprint requests: Associate Professor Dr Hasniah Abdul Latif. Department of Paediatrics, Faculty of Medicine, Universiti Kebangsaan Malaysia Medical Centre, Jalan Yaacob Latif, Bandar Tun Razak, 56000 Cheras, Kuala Lumpur, Malaysia. Tel: +603-9145 5380 Email: hasniah@ppukm. ukm.edu.my 
with subpleural cysts on High Resolution Computed Tomography (HRCT) thorax. This patient was born premature and had early onset pneumonia during the neonatal period. Subsequently, he had three episodes of pneumonias at 18, 19 and 26 months. He presented with recurrent symptoms of cough, wheeze, rapid breathing and had features of persistent airway obstruction characterized by chest hyperinflation, persistent tachypnoea with crepitations and rhonchi despite on regular bronchodilators. The only positive culture was Influenza B from his nasopharyneal aspirate culture. To our knowledge, this is the first reported case with both radiological entities in a child with Down syndrome.

Keywords: bronchiolitis obliterans, Down syndrome, subpleural cyst

\section{INTRODUCTION}

Down syndrome is the most common cause of chromosomal abnormalities in children (Thillainathan et al. 2014). They are characterised by having distinctive dysmorphic features of the head and neck with upslanting palpebral fissures, epicanthic folds, brachycephaly, Brushfield spots of the eyes, protruding tongue and excessive skin at the nape of the neck. The extremities features include short broad hands, single palmar crease, clinodactyly, widened sandal gap and hyperflexibility of the joints (Jones 2006; Epstein 2001).

The condition is also associated with several health conditions such as congenital heart disease (Benhaourech et al. 2016), congenital airway anomaly (Bertrand et al. 2003), genitourinary abnormalities (Faizah et al. 2011) and childhood leukaemia (Nurasyikin et al. 2012). The management involves a holistic approach and continuous evaluation to monitor for probable complications and disorders that are associated with this condition.
Respiratory infection is one of the most common reasons for hospitalization in children with Down syndrome. However, the available reports on pulmonary involvement in this group are limited (Yang et al. 2002; Gonzales et al. 1991; Joshi et al. 1986; Tyrrell et al. 1999; George et al. 2016; Biko et al. 2008). We wish to highlight the first reported case of a child with Down syndrome who had interesting radiological concurrent findings of bronchiolitis obliterans and diffuse subpleural cysts following recurrent pneumonias.

\section{CASE REPORT}

A 30-month-old boy with Down syndrome was born premature at 32 weeks with birth weight of 1.31 kg. He had early onset pneumonia required non-invasive ventilation and supplemental oxygen support for 18 days in neonatal intensive care unit. He had patent ductus arteriosus which was spontaneously closed at day 10 of life.

Subsequently, he had recurrent 


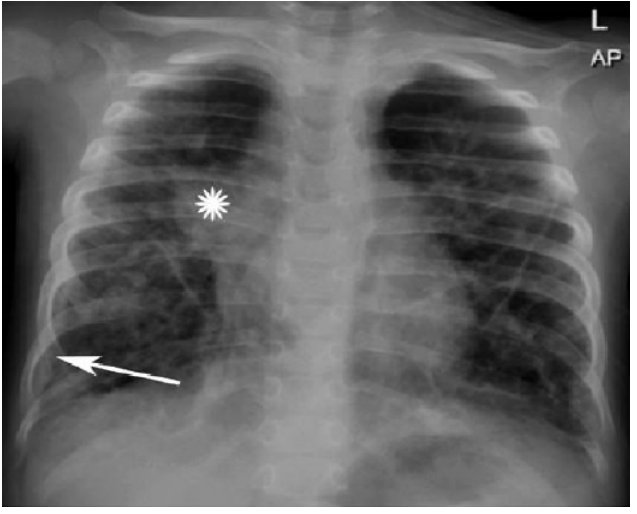

Figure 1: Anteroposterior chest radiograph done when he presented with acute pneumonia. There is bilateral interstitial opacities associated with focal consolidation at right hilar region $\left(^{*}\right)$. Bilateral minimal pleural effusion is also noted (white arrow)

admissions for pneumonias at 18, 19 and 26 months when he presented with recurrent symptoms of fever, cough and rapid breathing. During the first two admissions, he required supplemental oxygen, received a course of intravenous antibiotics and regular nebulised salbutamol for four to five days. Nasopharyngeal aspirate culture was positive for Influenza
$B$ in the second admission and he received a course of oseltamivir. In between admissions, there was history of intermittent chesty cough especially upon exertion. He was then started on inhaled steroid i.e. metered dose inhaler (MDI) fluticasone during his second admission.

Seven months later, he was readmitted with high grade fever associated with severe respiratory distress. Clinical examination revealed increased anteroposterior diameter of the chest, tachypnoea, right sided crepitations and generalised rhonchi. Chest X-ray (Figure 1) showed bilateral interstitial opacities and focal consolidation at right hilar region with minimal pleural effusion. He received supplemental oxygen for 1 week. Intravenous penicillin was commenced but later changed to intravenous cefuroxime and oral azithromycin was also added due to persistent fever. $\mathrm{He}$ also received regular nebulised salbutamol. He responded to treatment and was discharged after 2 weeks.

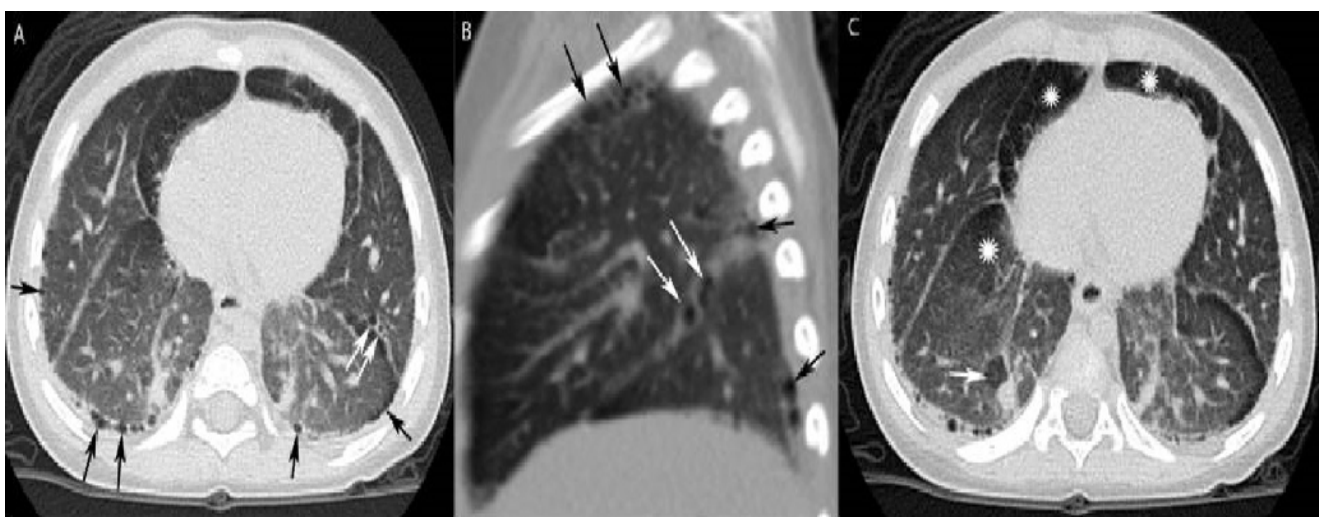

Figure 2: Lung window of CT thorax shows (A: axial \& B: sagittal) multiple air-filled cavities located at subpleural regions (black arrows) as well as along the major fissure (white arrow) (C: axial). There are also geographical areas of lucency in between the relatively denser normal lung parenchyma represents bronchiolitis obliterans $(*)$. HRCT thorax showed features of bronchiolitis obliterans and diffuse subpleural cyts 
In view of persistent lung findings, high resolution computed tomography (HRCT) thorax (Figure 2) was then performed which showed features of bronchiolitis obliterans with diffuse subpleural cysts.

Subsequently on follow up, he was well apart from having 1 episode of mild upper respiratory tract infection requiring oral antibiotics and needed infrequent use of MDI salbutamol. MDI fluticasone was then discontinued.

\section{DISCUSSION}

Diffuse parenchymal diseases among Down syndrome can develop as a primary process which includes pulmonary hypoplasia, pulmonary lymphangiectasia and interstitial lung diseases or due to secondary aetiologies such as post-infectious complications, cardiac and pulmonary vascular diseases and chronic aspiration. Children with Down syndrome are at an increased risk of respiratory infections compared to children without Down syndrome, to have a severe cause or even death due to respiratory causes (Hilton et al. 1999). A study in Netherlands showed that $53 \%$ of admissions among children with Down syndrome are due to lung infections (van Trotsenburg et al. 2006).

\section{Post-infectious bronchiolitis} obliterans is a rare disease that may occur following a microbiological insult towards the lower respiratory tract, causing a severe form of chronic obstructive airway disease. Pathologically, it is characterized by a fibrosing inflammatory process surrounding the bronchioles causing concentric obliteration and obliteration of small airways (Kurland \& Michelson 2005). Common aetiological agents include adenovirus, Mycoplasma pneumoniae, influenza, parainfluenza and respiratory syncytial virus (Kim et al. 2001). This patient developed bronchiolitis obliterans following recurrent chest infections and the only organism isolated was Influenza B virus.

The diagnosis of bronchiolitis obliterans in this patient was made based on his typical presentation of persistent cough, dyspnoea, wheeze and crackles, indicating chronic obstructive airway disease and characteristic features on HRCT thorax i.e. mosaic pattern representing areas of air-trapping. Interestingly, he also had concurrent features of diffuse cysts at the subpleural region and along the major lung fissures.

Management of bronchiolitis obliterans requires a multidisciplinary approach with care at expert centres. The discussion of the treatment of post-infectious bronchiolitis is limited compared to those of bronchiolitis obliterans post-lung or bone marrow transplantation. Although the prognosis of post-infectious bronchiolitis obliterans is often better compared to other types of bronchiolitis obliterans. However, the natural course of this condition is variable in each case and could not be expected certainly (Kavaluinaite \& Aurora 2019). Treatment with bronchodilator shows partial or no reversibility of airway obstruction compared to asthma. This is due to the damage caused by 
irreversible obstruction to the small airways (Zhao et al. 2017). The use inhaled and systemic costicosteroids was described to combat the ongoing inflammation and prevent airway fibrosis (Moonnumakal \& Fan 2008). Another study suggested that a combination of azithromycin and oral prednisolone offers certain benefits in treating these patients (Li et al. 2014).

The reported incidence of subpleural lung cysts in patients with Down syndrome was between $20-36 \%$. Pulmonary cysts occurred predominantly at peripheral areas, although some can appear at lung fissures and bronchovascular bundles (Gonzales et al. 1991; Biko et al. 2008). The exact mechanism of cysts formation in this group is not known. However, several contributing factors were postulated. It was first reported in 1986 by Joshi et al. (1986) whereby they discovered numerous small subpleural cysts on autopsy in two infants with Down syndrome and congenital heart disease. Gonzalez et al. (1991) in their autopsy review of 98 patients with Down syndrome also found that congenital heart disease was frequently associated with lung cysts. Co-existence of congenital heart disease is associated with greater occurrence of the cysts $(20 \%)$ compared to no congenital heart disease (4.3\%) (Tyrrell et al. 1999; George et al. 2016). The most common congenital heart disease in this group is endocardial cushion defect. However, there was no significant evidence to suggest any specific type of cardiac disease contribute to the development of lung cysts among them. Patent ductus arterious may be a contributing factor in this patient. This condition was also reported in previous series of patients with Down syndrome with lung cysts before, but no definite association can be made due to small number of patients in the study (Biko et al. 2008)

The cysts are less likely to be of congenital origin as previous autopsy reports of stillborn babies or fetuses with Down syndrome revealed no associated subpleural cysts (Joshi et al. 1986). Moreover, the airway and alveolar development continues into early postnatal life for in which contradicts to congenitally existence of cysts at the subpleural area.

Pulmonary hypoplasia might also be related to its development. Children with Down syndrome are found to have hypoplastic lung. There were diminished number of alveoli, a smaller alveolar surface area, and enlarged alveolar and alveolar ducts (Cooney \& Thurlbeck 1982). As postulated from previous study, this may result in the formation of cystic dilatation of the alveoli as a compensatory mechanism (Joshi et al. 1986). As children with Down syndrome are often born with low birth weight, (Rasmussen et al. 2006) we believe that this contributes to the atypical development of the lungs thus eventually causing cysts formation as this patient was born premature with birth weight on the $2^{\text {nd }}$ centile for his gestational age.

In patients with bronchiolitis obliterans, there is an increased risk of pneumothorax (Wang et al. 2015; Kurland \& Michelson 2005). In the presence of concurrent subpleural lung cysts, it is not known if there will 
be a higher risk for pneumothorax.

\section{CONCLUSION}

Clinicians should be aware that respiratory infections are common in patients with Down syndrome and those with recurrent pneumonias may lead to bronchiolitis obliterans. Subpleural lung cyst is a known occurrence among patients with Down syndrome. In patients with persistent respiratory signs and symptoms, further imaging i.e. HRCT thorax is required to establish the diagnosis of both entities.

\section{REFERENCES}

Benhaourech, S., Drighil, A., El Hammiri, A. 2016. Congenital heart disease and down syndrome: various aspects of a confirmed association, Cardiovascular Journal of Africa 27(5): 287-90.

Bertrand, P., Navarro, H., Caussade, S., Holmgren, N., Sanchez, I. 2003. Airway anomalies in children with down syndrome: endoscopic findings. Pediatric Pulmonol 36(2): 137-41.

Biko, D.M., Schwartz, M., Anupindi, S.A., Altes, T.A. 2008. Subpleural lung cysts in Down syndrome: prevalence and association with coexisting diagnoses. Pediatr Radio/ 38(3): 280-4.

Cooney, T.P., Thurlbeck, W.M. 1982. Pulmonary hypoplasia in Down's syndrome. N Engl J Med 307(19): 1170-3.

Epstein, C.J. 2001. Down syndrome (Trisomy 21). In: The metabolic and molecular bases of inherited disease, $8^{\text {th }}$ edition. Edited by Valle D, Vogelstein B, Antonarakis SE, Gibson KM. McGraw-Hill, New York; 1223.

Faizah, M.Z., Noorakmal, A., Syariz, I.S., Dayang, A.A., Tan, H.L. 2011. Recurrent epididymoorchitis: a clinical presentation of posterior urethral valve in a child with Down Syndrome. Med \& Health 6(1): 73-7.

George, M., Amodio, J., Lee, H. 2016. Cystic lung disease in Down syndrome: a case report and literature review. Case Reports in Paediatrics. 2016: 3 pages.

Gonzalez, O.R., Gomez, I.G., Recalde, A.L., Landing, B.H. 1991. Postnatal development of the cystic lung lesion of Down syndrome: suggestion that the cause is reduced formation of peripheral air spaces. Pediatr Pathol 11(4): 623-33.
Hilton, J.M., Fitzgerald, D.A., Cooper, D.M. 1999. Respiratory morbidity of hospitalized children with Trisomy 21. J Paediatr Child Health 35(4): 383-6.

Jones, K.L. 2006. Down syndrome. In: Smith's recognizable patterns of human malformation. $6^{\text {th }}$ edition, Elseviers Sauders, Philadelphia; 7.

Joshi, V.V., Kasznica, J., Ali Khan, M.A., Amato, J.J., Levine, O.R. 1986. Cystic lung disease in Down's syndrome: a report of two cases. Pediatr Patho/ 5: 79-86.

Kavaliunaite, E., Aurora, P. 2019 Diagnosing and managing bronchiolitis obliterans in children. Expert Rev Respir Med 13(5): 481-8.

Kim, C.K., Kim, S.W., Kim, J.S., Koh, Y.Y., Cohen, A.H., Deterding, R.R., White, C.W. 2001. Bronchiolitis obliterans in the 1990s in Korea and the United States. Chest. 120: 1101-6.

Kurland, G., Michelson, P. Bronchiolitis obliterans in children. 2005. Pediatr Pulmonol 39(3): 193208.

Li, Y.N., Liu, L., Qiao, H.M., Cheng, H., Cheng, H.J. 2014. Post-infectious bronchiolitis obliterans in children: a review of 42 cases. BMC Pediatr 14: 238.

Moonnumakal, S.P., Fan, L.L. 2008. Bronchiolitis obliterans in children. Curr Opin Pediatr 20(3): 272-8.

Nurasyikin, Y., Shenaz, S.K., Suria, A.A., Azma, R.Z., Zarina, A.L., Hamidah, A., Salwati, S., Zubaidah, Z., Hamidah, N.H. 2012. Infantile acute megakaryoblastic leukaemia with $\mathrm{t}(1: 22)$ in a non-Down syndrome child. Med \& Health 7(2): 112-9.

Rasmussen, S.A., Wong, L.Y., Correa, A., Gambrell, D., Friedman, J.M. 2006. Survival in infants with Down syndrome, Metropolitan Atlanta, 1979 1998. J Pediatr 148: 806-12

Thillainathan, S., Sirisena, N. D., Kariyawasam, K. W. J. C., Jayasekara, R. W., Dissanayake, V. H. W. 2014. Cytogenetic analysis of chromosomal abnormalities in Sri Lankan children. World Journal of Pediatrics 11(4): 374-9.

Tyrrell, V.J., Asher, M.I., Chan, Y. 1999. Subpleural lung cysts in Down's syndrome. Pediatr Pulmonol 28(2): 145-8.

van Trotsenburg, A.S., Heymans, H.S., Tijssen, J.G., de Vijlder, J.J., Vulsma, T. 2006. Comorbidity, hospitalization, and medication use and their infuence on mental and motor development of young infants with Down syndrome. Pediatrics 118(4): 1633-9.

Wang, W.P., Ni, Y.F., Wei, Y.N., Wei, Y.N., Li, X.F., Cheng, Q.S., Lu, Q. 2015. Bronchiolitis obliterans complicating a pneumothorax after Stevens Johnson syndrome induced by lamotrigine. J Formos Med Assoc 114(3): 285-9.

Yang, Q., Rasmussen, S.A., Friedman, J.M., 2002. Mortality associated with Down's syndrome in 
the USA from 1983 to 1997: a population-based study. Lancet 359(9311): 1019-25.

Zhao, C., Liu, J., Yang, H., Xiang, L., Zhao, S. 2017. Mycoplasma pneumoniae-associated bronchiolitis obliterans following acute bronchiolitis. Sci Rep 7(1): 8478.

Received: 30 Aug 2018

Accepted: 22 Apr 2019 